\title{
WORKING TOWARDS AN AFRICAN PEACEKEEPING CAPABILITY: KEY ISSUES, CHALLENGES AND DILEMMAS IN DARFUR
}

\author{
Prof Theo Neethling, Department of Political Science (Mil.) \\ Faculty of Military Science, Stellenbosch University
}

\section{Introduction}

The most violent and devastating conflicts on the African continent have notably been intra-state in nature: conflicts with considerable peacekeeping consequences for regional and international organisations. To this end, it is commonly accepted that there is a pressing need for African and other role-players to register progress on the need to address, manage and resolve the conflicts on the continent.

These issues are of great importance to the African continent, especially since the establishment of the African Union (AU) in Durban, South Africa, July 2002 was inter alia inspired by the desire to "promote peace, security and stability on the continent". The AU Constitutive Act - in stark contrast to the "noninterference' principle that underpinned the former OAU since 1963 - establishes in Article 4(h) the right of the Union to intervene in a member state pursuant to a decision of the Assembly (of heads of state or government) in respect of grave circumstances, namely war crimes, genocide and crimes against humanity. ${ }^{2}$ The Constitutive Act of the AU furthermore provides for action to "...promote and defend African common positions on issues of interest to the continent and its peoples", and it paves the way for "...the establishment of a common defence policy for the African continent". 3 Importantly, the African Heads of State and Government also agreed on the creation of an AU Peace and Security Council which, like its UN counterpart, would be in a position to deploy multinational contingents to conflicts when peace and security on the continent were threatened. ${ }^{4}$

The AU made significant progress in the development of a cohesive African peace and security system when African Chiefs of Defence Staff met in 
Addis Ababa in May 2003 where they agreed on the modalities of an African Standby Force (ASF). ${ }^{5}$ The notion of an ASF is basically intended to set up a multinational force empowered to intervene in serious conflicts around the troubled continent. Africa's leaders have accorded a high political priority to the concept and creation of an ASF. During his term as Chairman of the AU in 2002/2003, South African President Thabo Mbeki urged member states to give special priority to the establishment of an ASF to allow the continent to solve its conflicts. "Recent international events have confirmed the need for us Africans to do everything we can to rely on our own capacities to secure our continent's renaissance", Mbeki stated in 2003 prior to the annual meeting of Africa's foreign ministers in South Africa. ${ }^{6}$

Following the urge in recent years to deploy African peacekeepers in conflict-stricken areas under the auspices of the AU, the continental organisation has deployed peacekeepers in Burundi and most recently in Sudan. In both these cases deployment was organised on the basis of 'coalitions of the willing'. This said, it seems that the ASF concept is intended to provide the AU and other role-players on the African continent with a firmer foundation for undertaking peacekeeping endeavours and thus to move towards a less $a d h o c$ way of responding to crises than in past years. In terms of the new AU policy framework, the ASF will be deployed under the auspices of the AU to intervene in border wars and internal conflict. In practical terms, the ASF will consist of five sub-regionally based brigades (3 000 to 4000 troops) in addition to a sixth, continental, formation based at the AU's headquarters at Addis Ababa, Ethiopia. This will provide the AU with a combined stand-by capacity of 15000 to 20000 peacekeepers. ${ }^{7}$

Yet, it is commonly known that the African continent has had a critical impact on defining the limits and possibilities of the international peacekeeping regime. The problems and challenges that international peacekeepers have faced in this part of the world reflected the peculiar difficulties of peacekeeping itself. ${ }^{8}$ Past and recent experiences in conducting peacekeeping operations in Africa have indicated that such operations present serious challenges and a hostile operational environment to multinational forces assuming a peace support role. It has been acknowledged that most of the UN's serious challenges in the field of peacekeeping have been in African states, such as Somalia, Rwanda, Angola, Sierra Leone and most recently, the Democratic Republic of Congo.

A fundamental question is whether the $\mathrm{AU}$ would be in a position to really make a significant impact on peacekeeping challenges on the continent. In this regard Cilliers and Sturman rightly argued some time ago that "[t]he AU has a long 
way to go in turning the principle of intervention into workable practice... But the intention now expressed in the $\mathrm{AU}$ act is a huge step forward and a positive opportunity for change". However, they also pointed out that the resources that are made available to the AU will inevitably prove decisive - an issue to ponder given regular media reports to the effect that "[t]he African Union Mission in Sudan in its present strength is over stretched to address the security concerns" and that there "was the need to enhance the mission by increasing its strength and providing it with adequate logistical support". The mission furthermore "lacked basic elements of a balanced military force". 9 In view of the above, a pressing question is: what is to be learned from the recent AU experience in war-ravaged Sudan, specifically Darfur which has arguably become the most important regional challenge for $\mathrm{AU}$ peacekeeping endeavours in recent times?

A most important development relates to the fact that organisations in Africa have started to feature as important peacekeeping instruments in recent years as it is increasingly being accepted that there is a need for such institutions to take care of their own security requirements. The aim of this paper is to explore a number of key issues and challenges regarding the operationalisation of an effective AU peacekeeping capability in Africa and the political desire to work towards the successful conducting of multinational operations in support of peace and security in Africa. All of this requires a high degree of co-ordination between contributing nations and bodies, clear objectives and demands, and an enforcement capability based on the availability of adequately equipped and trained forces. Currently, the $\mathrm{AU}$ is faced by some serious dilemmas in Sudan - dilemmas that need careful scholarly analysis and assessment.

\section{Background}

It needs to be said that the notion of an ASF is not a new concept or PanAfrican ideal. During the 1960s and 1970s various calls for an African High Command were made in the former Organisation of African Unity (OAU) that a multinational military force be established. ${ }^{10}$ However, the envisaged African High Command never took shape beyond the planning stage, leading to a variety of ad hoc measures in the field of conflict resolution.

In 1981, the OAU sponsored the creation of a short-term all-African military force designed to resolve an expanding civil war in Chad. Composed of 4800 troops from the former Zaire (Democratic Republic of Congo), Nigeria and Senegal, this force failed to achieve any concrete solution. ${ }^{11}$ The mission did not succeed for a variety of reasons: inadequate planning, confusion over the mandate, 
absence of OAU command and control mechanisms, perceived partiality of some troop contributing countries, inadequate allocation of financial and logistical resources, and above all, lack of political will on the part of parties in conflict. As a first operation of this nature, it may, in the words of De Coning, perhaps best be described as "a useful learning experience". ${ }^{12}$

The second time the OAU deployed military personnel for peace support was in Rwanda in 1993. After the eruption of conflict in Rwanda and through concerted efforts by the OAU and neighbouring countries, the conflicting parties signed the Arusha agreement. As a result, the OAU deployed a Neutral Military Observer Group (NMOG) that monitored the Demilitarised Zone between the then Government of Rwanda and the Rwanda Patriotic Front. In this case, despite isolated incidents of cease-fire violations, the OAU and NMOG successfully maintained some degree of stability until the operation was handed over to the UN some months later. The assassination of Burundi's democratically elected President in October 1993 resulted in a breakdown of law and order. After the UN Security Council turned down a proposal from UN Secretary-General Boutros Boutros-Ghali to send a special mission to Burundi, the OAU organised a mission on its own. It was able to negotiate, among others, the deployment of the OAU Military Observer Mission to Burundi (OMIB). This was a confidence-building mission of military and civilian officers with a mandate of working towards the restoration of peace and security in Burundi. Initially, the mission fared well in keeping tensions down to a manageable level. ${ }^{13}$

Two developments underscored the OAU's ideal and desire to take a more systematic and proactive role towards conflict resolution in the post-Cold War era. Firstly, in 1993 the OAU Assembly of Heads of State and Government adopted a resolution creating the Mechanism for Conflict Prevention and Resolution, a formal consultative process ideally designed to prevent and resolve conflicts on the African continent. The inspiration for this consultative process was a forward-thinking document, Towards a Conference on Security, Stability, Development and Cooperation in Africa, popularly referred to as the Kampala document. ${ }^{14}$ The Mechanism had the following key objectives: to anticipate and prevent potential conflicts from escalating into major conflict or crises; and to undertake peacekeeping and peace-building in post-conflict situations. ${ }^{15}$

A second important development revolved around the possibility of creating a multinational African Defence Force, able to respond militarily to African crises. In May 1997, African leaders agreed that such a Force should be comprised of existing military units of OAU member states. Furthermore, such units would be 
equipped with the assistance of foreign powers, most notably the United States and France, although the Force would remain under the operational command of the OAU. Discussions, however, remained at an exploratory phase. Unresolved issues included which countries should be eligible to contribute forces (e.g. should involvement be limited to democratic states?) and what type of body should be able to authorise when and where to intervene (e.g. should intervention be based on consensus of all OAU member states or should a smaller body be responsible for such decision-making?). ${ }^{16}$ Thus the creation of an African Defence Force effectively remained a Pan-African ideal, but in the final analysis the OAU managed to mount observer missions and small operations in five countries, namely Rwanda, Burundi, the Comores, the DRC and Ethiopia-Eritrea. ${ }^{17}$

The establishment of the AU in 2002 and the adoption of the common defence and security policy in July 2004 should therefore be seen as a decisive step by the AU, bearing in mind the need for a holistic approach to develop appropriate responses to security crises on the continent. Moreover, the adoption of this document provided for the creation and development of the ASF as a military mechanism to deal with security crises on the continent. The formation of the ASF is indeed important, as it will be the manifestation of a long desired ideal in Africa to maintain a standby (peacekeeping) force on the continent.

It has already been noted that organisations in Africa have started to feature as important peacekeeping instruments in recent years as it is increasingly being accepted that there is a need for such institutions to take care of their own security requirements. A number of events have taken place in Africa that clearly suggest a trend that regional and sub-regional organisations are the first to respond to emerging crisis situations. Such organisations undertake short robust stabilisation or peace enforcement operations, and after some time, these operations are transformed into multidimensional UN peacekeeping missions. ${ }^{18}$ This division of labour between the UN and regional organisations appears to play into the strengths and compensate for the weaknesses of both types of organisations. The UN is relatively slow to respond to crises on the African continent. The regional organisations are not swift either, but they seem to be able to deploy somewhat sooner than the UN. Importantly, regional organisations are not required to meet the same criteria or minimum standards that the UN has adopted. Nor do they require units to meet the same level of readiness in terms of pre-deployment training or equipment tables. ${ }^{19}$ 


\section{Developing African peacekeeping capabilities: realities and challenges}

At a meeting in Addis Ababa in May 2003, the African Chiefs of Defence Staff swiftly moved to adopt a Policy Framework for the Establishment of the African Standby Force and the Military Staff Committee, drafted by African military experts. $^{20}$ The policy framework outlines six possible 'conflict and mission scenarios' the AU and the ASF are likely to face and will need to respond to in the foreseeable future: ${ }^{21}$

- Scenario 1 - AU/Regional military advice to a political mission.

- Scenario 2 - AU/Regional observer mission co-deployed with a UN mission.

- Scenario 3 - Stand alone AU/Regional observer mission.

- Scenario 4 - AU/Regional peacekeeping force for Chapter VI and preventive deployment missions.

- Scenario 5 - AU peacekeeping force for complex multidimensional mission with low-level spoilers (a feature of many current conflicts).

- Scenario 6 - AU intervention, e.g. genocide situations, where the international community does not act promptly.

Naturally, the speed with which forces would be required to deploy has particular implications for standby force structures and arrangements. In this regard, it has been recommended that deployment should be done in 30 days in the case of scenarios 1 to 4 . For scenario 5, complete deployment should be done in 90 days, with the military component being able to deploy in 30 days. Finally, it would be important for the AU to be able to deploy a robust military force in 14 days in the case of demanding and challenging intervention operations, as envisaged in scenario $6 .^{22}$

It was decided that the development of the ASF should become operational in two incremental phases. The first is aimed at developing a capacity to manage scenarios 1 to 3 , i.e. the conducting of observer missions. The second phase is aimed at developing a capability to deal with the remaining scenarios, i.e. classical peacekeeping to intervention operations towards $2010 .^{23}$ Sub-regions would be tasked with continuing to develop a capability to undertake a peacekeeping operation. Sub-regions that have managed to establish their standby brigades will be encouraged to enhance their rapid deployment capabilities. They would also be required to incorporate a small headquarters planning unit within the $\mathrm{AU}$ 
headquarters, as well as in each of the five sub-regions to plan and manage the size, mandate and structure of a standby peacekeeping force. ${ }^{24}$

It should be borne in mind that operations in the realm of peace and security are different from operations with a conventional focus, i.e. defence against external military aggression. These 'non-conventional' operations require deployments over vast distances; long-range logistical support; operating in a different geographical area, climate and terrain; and working with other armed forces. There is a realisation on the part of the AU that the recommendations of the (much discussed) Brahimi Panel on UN Peace Operations in 2000 have far-reaching implications for AU and regional peace support efforts, especially in the areas of organisation, equipment, training, doctrine and capacities. It is also acknowledged that the Panel's contention that "[t]here are many tasks which United Nations peacekeeping forces should not be asked to undertake and many places they should go" - especially in Africa - necessitates serious consideration of those issues relating to mission-capable forces on the African continent. ${ }^{25}$

This said, it should be noted that one of the realities of peacekeeping experience in Africa relates to financial constraints. In the past years, the extent of African peacekeeping was not limited by political will or the availability of troops, but rather by insufficient funding. Peacekeeping endeavours are by their very nature costly affairs. The recent peacekeeping experience is that even the relatively small and less logistically demanding unarmed military observer missions undertaken were so costly that the AU and its predecessor, the OAU, were unable to finance them from their own budget. It could be pointed out that the budget for the OAU Liaison Mission in Ethiopia and Eritrea (OLMEE) amounted to \$1.8 million per year in 2000. Its original planned strength was 43 civilian and military personnel, but it had an actual strength of 27 in 2000, comprising 11 military staff and 16 civilian support staff - directly as a result of financial constraints. ${ }^{26}$

The African Mission in Burundi (AMIB) has been considerably larger than any mission the AU, or the OAU before it, has undertaken. With 3335 personnel and an operational budget of approximately $\$ 110$ million in 2003, it represented a significant expense in the African peacekeeping context - especially when viewed against the AU budget of approximately $\$ 32$ million in $2003 .^{27}$ As the AU already stood in arrears of $\$ 40$ million from previous budgets in 2003, the AU had to depend on the strength and goodwill of 'lead nations' among its member states. $^{28}$ Regarding the future, the AU will have to meet the glaring financial realities of the high costs of peacekeeping missions if it would like the ASF to play any significant peacekeeping role in African conflict resolution and peacekeeping 
requirements. Some observers even contend that from a funding perspective, the only viable peacekeeping operations in Africa are UN (funded) peacekeeping operations. $^{29}$

Realising that financial and technical assistance would be pivotal to the successful development of the ASF, a joint Africa/G8 Action Plan was tabled and endorsed to enhance African capabilities to undertake peace support operations so that by 2010, African partners will be able to engage more effectively to prevent and resolve violent conflict on the continent. In this regard, it specifically provides for the establishment, equipment and training of coherent, multinational, multidisciplinary standby capabilities at the AU and sub-regional level which would be available for UN-endorsed missions undertaken under the auspices of the UN, AU or an African sub-regional organisation. ${ }^{30}$

Apart from financial and related challenges, AU and ASF functionaries furthermore have to attend to logistical and administrative aspects pertaining to the establishment of rosters of mission leadership, military, police and civilian experts as a requirement for proper mission start-up, as well as the capacity to plan and develop missions quickly. In addition, the need to establish unity of command and staff capacities for new missions has been identified as a top priority with a view to organising combined missions. Also, the quick disbursement of funds and procurement of essential goods will be an important component of any effective rapid deployment capability. ${ }^{31}$

In view of $\mathrm{AU}$ commitments to the ASF concept, four sub-regions initiated efforts to come to terms with the challenges of establishing sub-regional standby capabilities. At the end of October 2003 the Defence Chiefs of Staff of the Economic Community of Central African States (ECCAS) started to work towards a brigade-size sub-regional standby force. ${ }^{32}$ In Southern Africa, the Southern African Development Community (SADC), representing more than 50 per cent of SubSaharan Africa's Gross National Product and about 40 per cent of the region's area, ${ }^{33}$ also initiated efforts to come to terms with the challenges of establishing a sub-regional standby capability. Member states have already pledged over 6000 troops, the doctrine for peace missions has been finalised and a system of record management and financial reimbursement systems have been designed. ${ }^{34}$ According to reports, the planning towards the establishment of the SADC Standby Force Brigade, or SADCBRIG, is in an advanced stage. ${ }^{35}$

Likewise, ECOWAS and its 'military arm', the ECOWAS Cease-fire Monitoring Group (ECOMOG), that was set up in 1990 as a non-standing military 
force to deal with security problems in West Africa, took strong action in operationalising the ASF concept. In this regard, the ECOWAS Defence and Security Commission approved the establishment of a West African standby force of 6500 soldiers that could be deployed rapidly in response to crisis or threats to peace and security in the West African sub-region. The establishment of such force, to take over from the non-standing intervention force ECOMOG set up in 1990, was one of the decisions taken at the end of the Commission's $9^{\text {th }}$ session in Abuja, Nigeria, in June $2004 .^{36}$ The force would include a rapid reaction component of 1500 soldiers to be known as the ECOWAS Task Force, boosted with 3500 additional troops to form a brigade, while the remaining 1500 soldiers would constitute the reserve for the force. The Task Force will have the capability to be deployed within 30 days, while the brigade would have the capability not only to be deployed within 90 days, but also to be self-sustaining for 90 days. ${ }^{37}$

In a similar initiative, a meeting of eight Eastern African Chiefs of Defence Staff or their representatives was convened in February 2004 in Jinja, Uganda with a view to contemplating and kick-starting the establishment of the Eastern Africa Standby Brigade, or EASBRIG. ${ }^{38}$

Over and above, according to reports, significant progress has been made in recent times in that consensus has been reached on a range of matters regarding the envisaged ASF. These include the requirement for structure, doctrine, interoperability of forces, common training standards, as well as equipment and logistics. Resources are naturally one of the critical success factors and military planners seem to do their best to remain realistic that the force would have to be shaped in accordance with the resources that are made available in the context of national priorities of individual countries. ${ }^{39}$

At the same time, it could be argued that the process of establishing the ASF is still very much in the declaratory and macro-political phase - that is, that the more detailed issues of actual creation, support, command and operation have not been faced in practice. In other words, significant challenges and even problems remain in translating political statements and ideals into reality. This begs the question: what is to be learned from the recent $\mathrm{AU}$ experience in war-ravaged Sudan, specifically Darfur? The latter has arguably become the most important regional setting for AU peacekeepers in recent times, and in fact, has brought to light certain perspectives and lessons that require careful analysis and study. 
The AU Mission in Sudan: dilemmas and challenges

Sudan has been torn by conflict since independence in 1956. The longstanding civil war between the North and the South has left some 2 million people dead and many refugees have fled their homes or the country. Towards the end of 2003, the Sudanese government and the rebel Sudan People's Liberation Army (SPLA) reached a peace agreement mediated by Western role-players. However, strategic interests of outside powers, specifically with regard to Sudan's large oil deposits, and escalating turmoil in the western Darfur province, have rendered a swift conclusion on the peace agreement impossible. ${ }^{40}$ As the NorthSouth conflict eased in 2003, rebels in Darfur challenged the government and were met with fierce action and repression. According to estimates, tens of thousands of people have been killed and more than 1,8 million others displaced or have fled to neighbouring Chad since rebel groups took up arms against the Sudanese government over the distribution of economic resources. ${ }^{41}$

\section{Establishment of the AU mission in Darfur}

On 30 July 2004, the UN Security Council endorsed Resolution 1556, which provided for the deployment of a protection force by the AU in Darfur to monitor a cease-fire agreement concluded on 8 April 2004 between the Khartoum government and two rebel groups. The resolution also imposed an arms embargo on all militias or rebel groupings in Darfur. ${ }^{42}$ This paved the way for the AU to approve the African Mission in Sudan (AMIS) on 28 May 2005. The 'AMIS Plan' provided for 8 Battalions: 3 from Nigeria; 3 from Rwanda; 1 from Senegal and 1 from South Africa to be deployed from 30 September 2005. On 25 April 2005, during the $3^{\text {rd }}$ meeting of the Military Staff Committee of the Peace and Security Council in Addis Ababa it was recommended for the consideration of the Peace and Security Council that the military component of AMIS be composed of 6171 staff members (including 702 military observers). ${ }^{43}$ At the end of May 2005, the AMIS force levels were as follows: ${ }^{44}$

- 454 military observers;

- 245 civilian police;

- 26 international and Cease Fire Commission members; and

- 1647 soldiers as part of the protection force, contributed by Nigeria (587), Rwanda (392), South Africa (241), Gambia (196), Senegal (196), Kenya (35) and Mozambique $(1 \times$ strengthened company of approximately 280 men). 
A budget estimate of about US\$26 million was approved initially for the deployment and sustainment of AMIS. During the $3^{\text {rd }}$ Ordinary Session of the AU Assembly of Heads of State and Government, held in Addis Ababa from 6 to 9 July 2004, the initial budget was revised to an amount of about US\$43 million. Expectedly, much of this was based on donor funding from countries in the developed world. A detailed outline of contributions pledged and received as at 10 October 2004 is as follows: ${ }^{45}$

Canada:

Denmark:

European Union:

Germany:

Greece:

League of Arab States:

The Netherlands:

South Korea:

Sweden:

United Kingdom:

USA
US\$1 503759.40 (received)

US\$ 736664.25 (received)

US\$ 11080201.43 (received)

US\$ 1165120.00 (received; in addition Germany has donated communication equipment worth to Euro 100 000)

Euro 100000.00 (pledged)

US\$ 100000.00 (pledged)

US\$ 2000000.00 (paid for the provision of 3 helicopters for 3 months, including fuel)

US\$ 200000.00

US\$ 134066.23 (received)

US\$ 3676000.00 (received)

US\$ 6800000.00 (for contractual services for the purchase of office equipment, construction and maintenance)

Since 2005, substantial additional support to AMIS has been forthcoming from a number of donors. ${ }^{46}$ For instance, the United Kingdom has raised its contribution to AMIS to $\$ 34,65$ million in order to enable the AU to expand its peacekeeping capability. ${ }^{47}$ NATO has also helped to provide air transport for African troop contributing countries into Darfur. It has furthermore trained AU troops in strategic-level planning and operational procedures. In addition, several hundred AU officers have taken part in training provided by NATO. ${ }^{48}$ In fact, the $\mathrm{AU}$ has become almost totally dependent on external donations to sustain its Darfur operations.

Reporting on the situation in Darfur, the Secretary-General of the UN, Mr Kofi Annan, seemed to be quite pleased with the work done by AMIS since its inception. He described AMIS as a "groundbreaking initiative" for the AU and that AMIS "has accomplished a remarkable amount in a very short time", and that "in the areas where AMIS had deployed, it was doing an outstanding job under very 
difficult circumstances". He admitted, however, that while attacks on civilians were not occurring on the massive scale encountered in 2004, the violence continued and the general level of insecurity remained unacceptable. ${ }^{49}$

At the same time, it should be noted the UN Mission in Sudan (UNMIS) was established by the Security Council on 24 March 2005 after it had determined that the situation in the greater Sudan continued to constitute a threat to international peace and security. Specifically, it was decided that the task of UNMIS would be: to support the implementation of the Comprehensive Peace Agreement signed by the Sudanese government and the rebel SPLA at the end of 2003; to facilitate and coordinate, within its capabilities and in its areas of deployment, the voluntary return of refugees and internally displaced persons and humanitarian assistance; to assist the parties in the demining sector; and to contribute to international efforts to protect and promote human rights in Sudan. ${ }^{50}$ Thus whereas AMIS was basically tasked to deal with escalating violence and human rights violations in Western Darfur, UNMIS has been tasked to oversee the broader peace agreement reached with a view to dealing with the longstanding North-South conflict.

\section{Insecurity in Darfur}

Towards the middle of 2006 AMIS peacekeepers totalled about 7000 troops and observers, but never really succeeded in bringing security to war-torn Darfur province. Soon media coverage became progressively critical. Media reports on AMIS has generally pointed towards AMIS as "overstretched" and that it lacked the capacity to perform the monitoring and verification required of it. ${ }^{51}$ Pepper and McLaughlin, writing in The Christian Science Monitor have even been more to the point: ${ }^{52}$

Amid rising insecurity in Darfur, even routine patrols have become dangerous... Since its inception in 2004, the African Union's mission to Darfur has been a major test of Africa's collective ability to defuse its own conflicts and protect its civilians... The final verdict isn't in, but it's clear AU troops are struggling often in vain to calm Darfur, a region the size of Texas where attacks by government-backed Arab militias began in 2003 against indigenous-African villages.

The Global Policy Forum likewise stated that AMIS "has been left undermanned, poorly funded and ill-equipped to respond to the rapidly deteriorating conflict". In a frank and even more assertive approach, former AMIS Military Advisor, Commander Seth Appiaf-Mensah, stated that "...the mission has come under serious international pressure to respond appropriately to the deteriorating 
situation on the ground by enhancing its presence and effectiveness". He also acknowledged that "...serious challenges continue to undermine the mission's effectiveness and its prospects, not the least of these obstacles being adequate funding". 53

AMIS also experienced some problems with its mandate. From the inception of the mission, many high-profile personalities and groups, particularly NGOs and the media, have advocated a more robust mandate that would enable the mission to extend its protection to civilians in Darfur. ${ }^{54}$ Having suffered fatalities towards the end of 2005 , critics especially started to contend strongly that the AMIS mandate was not robust enough for commanders to protect civilians in danger within their capability and within their capacity. ${ }^{55}$ In view of this, Appiaf-Mensah for instance, argues that "the mission is in a dilemma with respect to its mandate" ${ }^{56}$ These views are confirmed by similar sentiments that AMIS "has an insufficient mandate and inadequate international support". 57 More specifically, Pepper and McLaughlin argue that "AU troops are only allowed to use force to protect themselves - or civilians in their immediate vicinity. Most experts agree that this limited mandate severely hampers their ability to secure the area" ${ }^{58}$ In other words, it could be said that whereas AMIS is mandated to exercise peacekeeping operations, it should actually be mandated to apply enforcement operations. Pepper and McLaughlin furthermore reported as follows on the situation in Darfur: ${ }^{59}$

"This peacekeeping mission is unique. I've been in Bosnia where there were lines of separation, but here there is nothing like that. Here there is no separation, rules, lines, clear zone of occupation," says an exasperated Colonel Vitalis Ajumbo, a Kenyan who oversees one of the region's more volatile sectors. Last week, the UN grounded some helicopters, because a renegade rebel group threatened to shoot them down. "Our humanitarian efforts are being destroyed on the ground," said UN spokeswoman Radhai Achouri.

Against this background, a joint AU, UN, US and EU team in Darfur assessed the feasibility of a UN force in Darfur towards the end of 2005 . $^{60}$ In the words of the Middle East Times reporter: "The cash-strapped AU mission in Sudan has been under pressure to hand over its Darfur operations to the United Nations". 61 On 10 March 2006 a communiqué of the $46^{\text {th }}$ meeting of the Peace and Security Council of the AU stated that the AU resolved to extend the mandate of AMIS for six months in the hope to reaching a peace agreement between the Sudanese government and the rebel groups. At the same time the AU agreed to support in principle transforming AMIS into a UN force with the expiring of its mandate at the 
end of September 2006. The decision represented a compromise between the wishes of countries such as the US and France, who wanted the UN to take over and reinforce the AU force as soon as possible, and the Sudanese government, which hoped to keep the UN from assuming control of the mission. Shortly after, in its Resolution 1679 of 16 May 2006, the UN Security Council expressed the intention to speed up the transition of AMIS to a larger UN force in Darfur. ${ }^{62}$ The International Crisis Group also urged that the Security Council should authorise deployment of a robust UN force, starting with a rapid reaction component, to take over from AMIS by 1 October 2006, with a clear Chapter VII mandate to use all necessary means to protect civilians and assist in the implementation of the peace plan. $^{63}$

It also needs to be said that media reports in South Africa referred to unhappiness among South African troops deployed in Darfur regarding deployment conditions. It was reported that South African soldiers deployed in Sudan earned far less that their colleagues serving as UN 'blue berets' in the DRC and Burundi. Also, in August 2005, the South African contingent was reportedly informed that their daily allowance would be cut from $\$ 25$ per day to $\$ 1$ per day in view of financial problems on the part of the AU. ${ }^{64}$ Be that as it may, there can be no doubt that " $[\mathrm{t}]$ he African Union's mission in Sudan has become a test of its ability to quell conflicts successfully" 65 - which does not bode well for the future operationalisation and deployment of the ASF.

On 5 May 2006 the Khartoum government and the main Darfur rebel faction signed a peace agreement, brokered by the AU, in the Nigerian capital, Abuja, after days of intense talks. ${ }^{66}$ On 31 August 2006 UN Security Council Resolution 1706 welcomed the efforts of the AU to find a solution to the crisis in Darfur, but at the same time reaffirmed its concern that the ongoing violence in Darfur may further negatively affect the rest of Sudan as well as the region, in particular Chad and the Central African Republic, and stressed that regional security aspects had to be addressed to achieve long lasting peace in Darfur. Significantly, the Security Council also recalled the decision of the AU Peace and Security Council of 10 March 2006, and a subsequent decision of 27 June 2006, that the AU was ready to review the mandate of AMIS. Moreover, the Security Council decided that UNMIS (the UN mission in Sudan) should be strengthened by up to 17300 military personnel and by an appropriate civilian component including up to 3300 civilian police personnel - in order that it may deploy in Darfur. ${ }^{67}$ However, the Sudanese government vowed that the regime would maintain its opposition to a UN peacekeeping force for Darfur and even hailed Hezbollah as a model of resistance. In the words of Vice-President Ali Osma Taha: "We have options and plans for 
confronting the international intervention", adding that "...we are prepared for all possibilities". ${ }^{6}$ At the time of writing the Security Council decided to extend the mandate of AMIS to 31 December $2006 .{ }^{69}$

\section{Appraisal and conclusion}

It is clear from the above that the $\mathrm{AU}$ has made progress in the development of a comprehensive and cohesive peace and security policy framework in recent times. Although many practical issues and principles guiding interventions have yet to be thrashed out at specific functional levels, the AU's common defence and security policy certainly represents a meaningful advance in conceptual thinking concerning the parameters and principles of regional or coalition peace operations in Africa. Furthermore, the ASF clearly represents a serious intention on the part of African leaders to set up a multi-national military force empowered to intervene militarily in serious conflicts around the troubled continent. African leaders seem to be keen to avoid a repeat of genocide such as in Rwanda in 1994 when extremists from the Hutu majority slaughtered an estimated 800000 minority Tutsis and Hutu moderates in 100 days of killings. If planning comes to fruition, Africa should have a six brigade UN-style force ready to police the continent's conflicts by the end of this decade. All in all, the formation of an ASF is of great significance as it is the development of the ability, long desired, for Africa to police its trouble spots.

While there is no lack of political support for the development of the ASF, valid concerns persist about the financial implications of implementing such objectives. As the AU and African sub-regions look to operationalise the ASF, the significant costs related to its establishment led African leaders to seek support from the international community. In this regard they managed to mobilise technical and financial assistance so that, by 2010, African role-players would hopefully be in a position to engage more effectively to prevent and resolve violent conflict on the continent, and to undertake peacekeeping operations in accordance with the UN Charter.

A great deal of the practical challenges and responsibility for developing the ASF are in the hands of African organisations and functionaries themselves. Thus, if the AU aspires to become a leading organisation in Africa's conflict resolution requirements, in the words of Kent and Malan, it needs to "seize the opportunity to implement the provisions of the (AU) Constitutive Act. Its success will rightly be judged on whether it can and will respond to situations of armed conflict and on the extent to which the presence of AU or regional peacekeeping 
forces will manage the strategic and operational challenges required to resolve complex multidimensional peace support or enforcement operations". ${ }^{70}$

But all of this is theoretical and if the AU's recent experience in Darfur is to be taken as a yardstick or barometer of any kind, it would seem that the AU's plan to work towards intervention operations towards 2010 is quite ambitious. Even if viable, it is perhaps only viable to the extent that the ASF could play a crucial role in stabilising a crisis situation for a limited period of time. Over a longer period of time the momentum of a peace mission should not be lost and the UN is really the only institution that could co-ordinate the various multidimensional components needed to form a complex peacekeeping operation and peacebuilding system. As De Coning rightly argues: "The AU and African regional organisations thus do not have the capacity to undertake complex peacekeeping operations on their own."71 They would need to join forces with other institutions like the UN, donor agencies and NGOs whenever they were to deploy in a complex peace operation context." At the same time, it is also true that UN peacekeeping operations are not necessarily well suited for peace enforcement. Regional organisations, on the other hand, are typically led and commanded by a strong lead nation, and this type of force structure is better suited for enforcement action. ${ }^{72}$ In view of the above, it would seem that Africa's regional organisations, which have been identified as the building blocks or operational units of the ASF, would need to go a very long way to the point where they could undertake complex multidimensional operations. Recent challenges and operations in Darfur once again underscore the financial and logistical challenges associated with peacekeeping and even suggest that the AU is too ambitious in its future plans concerning the deployment of ASF brigades in terms of the full range of scenarios envisaged for the ASF. On the basis of the Darfur experience, it would rather be advisable to plan for the successful conducting of military observer missions and short-term stabilisation operations.

In the final analysis, given the timeframes for developing the ASF, it could be stated that the process of establishing the ASF is still very much in the declaratory and macro-political phase - that is, that the more detailed issues of actual creation, support, command and operation have not been faced in practice. In other words, significant challenges and even problems remain in translating political statements and ideals into reality. To that extent, it may be argued that the process still is something in the realm of a paper, or wishing phase, and could even become derailed or stalled. The reality on financing especially seems to support to a significant degree this interpretation regarding a 'declaration-reality gap'. At the same time, it could be premature to raise too many reservations on the future of the ASF. After all, it will take some time to create and establish the conditions to 
sustain the complete range of capabilities needed to fully undertake complex peacekeeping operations and their related activities. But this will have to be realised by the politicians and planners involved in the operalisation of the ASF.

\section{References}

${ }^{1}$ See Article 3(f) of the Constitutive Act of the African Union.

${ }^{2}$ G8, Implementation Report by Africa Personal Representatives to Leaders on the G8 Africa Action Plan, G8 Summit, Evian, France, 1-3 June 2003, www.au2002.gov.za/docs/releases/g8030604b.htm.

${ }^{3}$ See Article 3(d) and Article 4(d) of the Constitutive Act of the African Union respectively.

${ }^{4}$ R Munusamy, "States Vie for Power in the African Union", Sunday Times, 7 July 2002, p.1.

${ }^{5} \mathrm{C}$ de Coning, "Towards a Common Southern Africa Peacekeeping System", CIPS Electronic Briefing Paper, 16, 2004, p.4.

6 AFP, "Mbeki Wants Standby Force Prioritised", Business Day, 23 May 2003, www.bday.co.za/bday/content/direct/1\%2C3523\%2C1352396-6098-0\%2C00.html.

${ }^{7}$ EA Thorne, "The African Standby Force Takes Shape: An Observation of Needs and Necessary Actions", African Armed Forces Journal, July 2003, p.26.

${ }^{8} \mathrm{C}$ Clapham, The United Nations and Peacekeeping in Africa. Paper presented at a symposium on International Peace and Security: The African Experience, SA Military Academy, Saldanha, 21-23 September 1998, p.1.

${ }^{9}$ African Union, Peace and Security Council Military Staff Committee, 3rd Meeting of the Military Staff Committee of the Peace and Security Council, Addis Ababa, Ethiopia, 25 April 2005, p.2.

${ }^{10}$ M Hough, "Military Intervention in Sub-Saharan Africa", in Managing African Conflicts: The Challenge of Military Intervention, L du Plessis and M Hough, eds., Pretoria: HSRC Publishers, 2000, p.184.

$11 \mathrm{P}$ Schraeder, African Politics and Society: A Mosaic in Transformation, $2^{\text {nd }}$ edition, Wadsworth: Belmont, 2004, p.258.

${ }^{12} \mathrm{C}$ de Coning, "The Role of the OAU in Conflict Management in Africa", in Conflict Management, Peacekeeping and Peace-building: Lessons for Africa from a Seminar Past, Mark Malan, ed., Pretoria: Institute for Security Studies, April 1997, p.20.

${ }^{13}$ Ibid, pp.20-21.

${ }^{14}$ P Schraeder, op cit, pp.258-259.

15 'F Olonisakin, "Conflict and Conflict Resolution", in Power, Wealth and Global Equity: An International Relations Textbook for Africa, P McGowan and P Nel, eds., UCT Press: Cape Town, 2002, p.243.

${ }^{16} \mathrm{P}$ Schraeder, op cit, p.259.

${ }^{17} \mathrm{~J}$ Cilliers and M Malan, "Progress with the African Standby Force", ISS Paper, 107, May 2005, p.1.

${ }^{18}$ C de Coning, "Refining the African Standby Force Concept", Conflict Trends, 2, 2004, p.22.

${ }^{19}$ Ibid, p.23.

${ }^{20}$ V Kent and M Malan, "The African Standby Force: Progress and Prospects", African Security Review, 12, 3, 2003, p.73.

${ }^{21}$ African Union, Policy Framework for the Establishment of the African Standby Force and Military Staff Committee, adopted by the African Chiefs of Defence Staff, Addis Ababa, Ethiopia, 15-16 May 2003, p.3.

${ }^{22}$ Ibid, p.7.

${ }^{23}$ C de Coning, "Peacekeeping Trends", Conflict Trends, 4, 2003, pp.30-31.

${ }^{24} \mathrm{~V}$ Kent and M Malan, op cit, p.74.

${ }^{25}$ African Union, op cit, p.9.

${ }^{26} \mathrm{C}$ de Coning, 2003, op cit, p.34. 
${ }^{27}$ Ibid.

${ }^{28} \mathrm{~V}$ Kent and M Malan, op cit, p.73.

${ }^{29} \mathrm{C}$ de Coning, 2004, op cit, p.5.

${ }^{30} \mathrm{G} 8$, op cit.

${ }^{31} \mathrm{Ibid}$.

${ }^{32} \mathrm{C}$ de Coning, 2004, op cit, p.20.

${ }^{33}$ PJ McGowan, "The Regional Sub-System of Southern Africa", in Power, Wealth and Global Equity: An International Relations Textbook for Africa, P McGowan and P Nel, eds., UCT Press: Cape Town, 2002, p.243.

${ }^{34}$ Centre for International Political Studies (University of Pretoria), "Press Statement: The Status of the African Stand-By Force: A SADC Perspective, Brig Gen Les Rudman, Director: Military Strategy, SANDF", Africa Dialogue Lecture, 20 September 2005, p.2.

${ }^{35}$ D, Ndaba, "Pondering Security and Peace", Salut 12, 6, 2005, p.35.

${ }^{36}$ PANA, "West African Commission Endorses Standing Force", Panapress, 19 June 2004, www.panapress.com/freenews.asp?code=eng046289\&dte=19/06/2004.

${ }^{37}$ AFP, "West African Defense Chiefs Establish 'Rapid Reaction Force'“, SpaceWar, 18 June 2004, www.spacewar.com/2004/040618200925.cjswes.fy.html.

${ }^{38}$ Anon, "East African Standby Brigade Will Help End Wars in Somalia", GEESKA AFRIKA ONLINE DAILY NEWS AND VIEWS, 13 April 2004, www.geeskaafrika.com/somalia_13apr05.htm.

${ }^{39}$ R Hauter, The Challenges of Military Strategy. Paper presented at a symposium on Strategic Challenges for South Africa, University of Pretoria, 27 February 2003, p.2.

40 Global Policy Forum, Sudan, undated, www.globalpolicy.org/security/issues/sudanindex.htm.

${ }^{41}$ United Nations, "Sudan - UNMIS - Background: United Nations Mission in the Sudan", undated, www.un.org/Depts/dkpo/missions/unmis/background.html.

${ }^{42}$ Global Policy Forum, op cit.

${ }^{43}$ African Union, $3^{\text {rd }}$ Meeting of the Military Staff Committee of the Peace and Security Council of the Peace and Security Council, Addis Ababa, Ethiopia, 25 April, 2005, pp.2-3.

${ }^{44}$ H Boshoff, "The African Union Mission in Sudan", African Security Review, 14, 3, 2005, www.iss.co.za/index.php?link_id=3\&slink_id=1898\&link_type=12\&slink_type=12tmpl_id=3.

${ }^{45}$ African Union, $17^{\text {th }}$ Meeting of the Peace and Security Council, Addis Ababa, Ethiopia, 20 October 2004, pp.2-3.

${ }^{46}$ S Appiah-Mensah, "The African Mission in Sudan: Darfur Dilemmas", African Security Review, 15, 1, 2006, p.5.

${ }^{47}$ UN Office for the Coordination of Humanitarian Affairs, "Sudan: British Funding for AU Mission in Darfur Increased", 17 June 2005, www.globalsecurity.org/military/library/news/2005/06/mil-0506617-irin02.ttm.

48 NATO, "NATO's Assistance to the African Union for Darfur", 23 June 2006, www.nato.int/issues/darfur/index.html.

${ }^{49}$ Secretary-General of the UN, Report of the Secretary-General on United Nations Assistance to the African Union Mission in Sudan, 3 May 2005, pp.2, 5.

${ }^{50}$ United Nations, "Sudan - UNMIS - Background: United Nations Mission in the Sudan", www.un.org/Depts/dkpo/missions/unmis/background.html.

${ }^{51}$ International Crisis Group, "Darfur's Fragile Peace Agreement", Africa Briefing, 39, 20 June 2006, www.crisisgroup.org/home/index.cfm?id=4179\&1=1.

${ }^{52}$ D Pepper and A McLaughlin, "AU struggles to Calm Darfur", Christian Science Monitor, 12 December 2005, www.csmonitor.com/2005/1212/p06s01-woaf.html.

${ }^{53} \mathrm{~S}$ Appiah-Mensah, op cit, p.1.

${ }^{54}$ Ibid.

${ }^{55}$ D Pepper and A McLaughlin, op cit. 
${ }^{56}$ Ibid, p. 11.

${ }^{57}$ Global Policy Forum, op cit.

${ }^{58}$ D Pepper and A McLaughlin, op cit.

${ }^{59} \mathrm{Ibid}$.

${ }^{60}$ Ibid.

${ }^{61}$ Mohammed Ali Saeed, "Sudan Upbeat after Darfur Mission Extension”, Middle East Times, 12 March 2006, www.metimes.com/print.php?StoryID=20060313-045125-2523r.

${ }^{62}$ Global Policy Forum, op cit.

${ }^{63}$ International Crisis Group, "Darfur's Fragile Peace Agreement", Africa Briefing, 39, 20 June 2006, www.crisisgroup.org/home/index.cfm?id=4179\&1=1.

${ }^{64}$ E Gibson, "Vredesoldate van SA moet langer bly" ('SA peacekeepers must stay longer'), Die Burger, 5 September 2005, p.5.

${ }^{65} \mathrm{D}$ Pepper and A McLaughlin, op cit.

${ }^{66}$ BBC, "Main Parties in Darfur sign Darfur Accord", BBC News, 5 May 2006, news.bbc.co.uk/2/hi/africa/4978668.stm.

${ }^{67}$ UN Security Council, Resolution 1706, 2006, Adopted by the Security Council at its $5519^{\text {th }}$ meeting, 31 August 2006, pp.2, 3.

${ }^{68} \mathrm{H}$ Hanekom, Africa Institute of South Africa: News Flashes from Africa, NFA 165, 4 September 2006, p.4.

${ }^{69}$ UN Security Council, Resolution 1714, 2006, Adopted by the Security Council at its $5545^{\text {th }}$ meeting, 6 October 2006, p.2.

${ }^{70} \mathrm{~V}$ Kent and M Malan, op cit, p.79.

${ }^{71} \mathrm{C}$ de Coning, 2004, op cit, pp.22-23.

${ }^{72}$ Ibid. 